\title{
Effect of Microstructure on the Mechanical Properties of Magnesium Composites Containing Dispersed Alumina Particles Prepared Using an MM/SPS Process
}

\author{
Hiroshi Fujiwara ${ }^{1}$, Suguru Hamanaka ${ }^{2}$, Shigehiro Kawamori ${ }^{3}$ and Hiroyuki Miyamoto ${ }^{1}$ \\ ${ }^{1}$ Department of Mechanical and Systems Engineering, Doshisha University, Kyotanabe 610-0394, Japan \\ ${ }^{2}$ Graduate School, Doshisha University, Kyotanabe 610-0394, Japan \\ ${ }^{3}$ Department of Intelligent Mechanical Systems, Tamagawa University, Tokyo 194-8610, Japan
}

\begin{abstract}
Magnesium composites containing 0-20 vol\% $\mathrm{Al}_{2} \mathrm{O}_{3}$ particles were produced via mechanical milling (MM) followed by spark plasma sintering (SPS), and the effect of the microstructure on their mechanical properties was investigated. Microstructural observation of the MM powders and SPS compacts was achieved using scanning electron microscopy (SEM), X-ray diffraction (XRD), and transmission electron microscopy (TEM)/energy dispersive X-ray spectroscopy (EDS). The mechanical properties of the MM powders and SPS compacts were evaluated on the basis of the results of the Vickers hardness test. SEM micrographs indicated that $\mathrm{Al}_{2} \mathrm{O}_{3}$ fine particles were dispersed in the $\mathrm{Mg}$ composites with 10 and 20 vol\% $\mathrm{Al}_{2} \mathrm{O}_{3}$. The hardness values for the $\mathrm{MM}$ powder and the SPS compact containing 10 vol\% $\mathrm{Al}_{2} \mathrm{O}_{3}$ were nearly the same owing to their similar microstructures. However, the hardness of the SPS compact was higher than that of the MM powder for the Mg composite with $20 \mathrm{vol} \% \mathrm{Al}_{2} \mathrm{O}_{3}$. TEM/EDS and XRD analyses revealed that the needle-like $\mathrm{Mg}_{17} \mathrm{Al}_{12}$ and equiaxed nano MgO particles formed in the $\mathrm{Mg}$ matrix with $20 \mathrm{vol} \% \mathrm{Al}_{2} \mathrm{O}_{3}$ during the SPS process. The increase in hardness of the SPS compact compared to that of the MM powder is attributed to strengthening resulting from the formation of the $\mathrm{Mg}_{17} \mathrm{Al}_{12}$ and $\mathrm{MgO}$ phases. [doi:10.2320/matertrans.Y-M2013845]
\end{abstract}

(Received August 19, 2013; Accepted December 16, 2013; Published January 31, 2014)

Keywords: mechanical milling, spark plasma sintering, $M_{17} A l_{12}$ phase, magnesium oxide

\section{Introduction}

Magnesium has a lower specific gravity than that of aluminum and the demand for $\mathrm{Mg}$ alloys has recently increased compared to that for Al alloys. However, nearly all $\mathrm{Mg}$ alloys are inferior to $\mathrm{Al}$ alloys with respect to their mechanical properties. Recently, composites of magnesium and ceramic particles have received much attention owing to the improvement in the mechanical properties of these $\mathrm{Mg}$ materials. ${ }^{1-5)}$ Particularly in the composite of magnesium and alumina, Hassan and $\mathrm{Gupta}^{6-9)}$ reported that $\mathrm{Mg}$ composites containing up to 1.1 vol\% fine $\mathrm{Al}_{2} \mathrm{O}_{3}$ particles were produced using a powder metallurgy technique and exhibited superior mechanical properties. However, literature concerning $\mathrm{Mg}$ composites containing more than $10 \mathrm{vol} \%$ fine $\mathrm{Al}_{2} \mathrm{O}_{3}$ particles is limited. One of the present authors recently revealed that compacted $\mathrm{Mg}$ composites containing 10 $30 \mathrm{vol} \%$ fine $\mathrm{Al}_{2} \mathrm{O}_{3}$ particles can be produced via mechanical milling (MM) followed by spark plasma sintering (SPS) or a hot pressing and that the optimal $\mathrm{Al}_{2} \mathrm{O}_{3}$ composition to enhance the mechanical properties falls between 10 and 20 vol\%. ${ }^{10-13)}$ However, the effect of the microstructure on the mechanical properties of $\mathrm{Mg}$ composites containing more than $10 \mathrm{vol} \% \mathrm{Al}_{2} \mathrm{O}_{3}$ is not yet clear. The purpose of this paper is to clarify the relation between the microstructure and the mechanical properties of the $\mathrm{Mg}$ compacts containing 10 to $20 \mathrm{vol} \%$ fine $\mathrm{Al}_{2} \mathrm{O}_{3}$ particles that are produced using the $\mathrm{MM} / \mathrm{SPS}$ processes.

\section{Experimental Procedure}

Commercially pure $\mathrm{Mg}$ powder ( 99.5 mass $\%$ purity) and $\alpha-\mathrm{Al}_{2} \mathrm{O}_{3}$ powder ( 99.9 mass $\%$ purity) were used in this study. The initial particle sizes of the pure $\mathrm{Mg}$ and $\mathrm{Al}_{2} \mathrm{O}_{3}$ powders were approximately 180 and $1 \mu \mathrm{m}$, respectively. Mechanical milling (MM) was applied to these powders using an attritor ball mill (Mitsui Mining Co., Ltd.) under Ar atmosphere at room temperature. Mixed powders consisting of pure $\mathrm{Mg}$ and $0-20 \mathrm{vol} \% \mathrm{Al}_{2} \mathrm{O}_{3}$ were mechanically milled for $180 \mathrm{ks}$ at an agitator arm rotation speed of $300 \mathrm{rpm}$. Stearic acid ( 2 mass $\%$ ) was added as a lubricant. A mixed powder of $200 \mathrm{~mL}$ of $\mathrm{Mg}$ and $0-20$ vol\% $\mathrm{Al}_{2} \mathrm{O}_{3}$ was fed into $\mathrm{Al}_{2} \mathrm{O}_{3}$ container (capacity $5.5 \mathrm{~L}$ ) along with $3 \mathrm{~L}$ of $\phi 5 \mathrm{~mm} \mathrm{Al}_{2} \mathrm{O}_{3}$ balls. The composite $\mathrm{MM}$ powders containing the pure $\mathrm{Mg}$ and $\mathrm{Al}_{2} \mathrm{O}_{3}$ were then sintered using a spark plasma sintering (SPS) apparatus (SPS-515S; SPS Syntex Co., Ltd.) at $848 \mathrm{~K}$ and $40 \mathrm{MPa}$ for $0.6 \mathrm{ks}$ and the composite discs with about $\phi 20 \mathrm{~mm}$ were obtained. The microstructural observation of the MM powders and SPS compacts containing $\mathrm{Mg}$ and $\mathrm{Al}_{2} \mathrm{O}_{3}$ was achieved using scanning electron microscopy (SEM), X-ray diffraction (XRD), and transmission electron microscopy (TEM)/energy dispersive X-ray spectroscopy (EDS). The samples for SEM and TEM analysis were prepared using an ion-beam polish and focused ion beam system, respectively. A spot size for EDS analysis used $1.0 \mathrm{~nm}$. XRD profiles were measured under the condition of diffraction angle of 20-90 degree, tube voltage of $40 \mathrm{kV}$ and tube current of $40 \mathrm{~mA}$. The mechanical properties of the MM powders and SPS compacts were evaluated using the Vickers hardness test at 0.098 and $9.8 \mathrm{~N}$, respectively, for $15 \mathrm{~s}$.

\section{Results and Discussions}

\subsection{Microstructure and hardness of the MM powders and SPS compacts}

Figure 1 shows SEM micrographs of the MM powders containing $0-20 \mathrm{vol} \% \mathrm{Al}_{2} \mathrm{O}_{3}$ particles. The pure $\mathrm{Mg}$ powder milled for $180 \mathrm{ks}$ can be seen in Fig. 1(a), and the composite $\mathrm{MM}$ powders with 10 and $20 \mathrm{vol} \% \mathrm{Al}_{2} \mathrm{O}_{3}$ particles can be seen in Figs. 1(b) and 1(c), respectively. The MM treatment decreased the size of the initial $\mathrm{Mg}$ particles and distributed fine $\mathrm{Al}_{2} \mathrm{O}_{3}$ particles homogeneously within the $\mathrm{Mg}$ powder. 

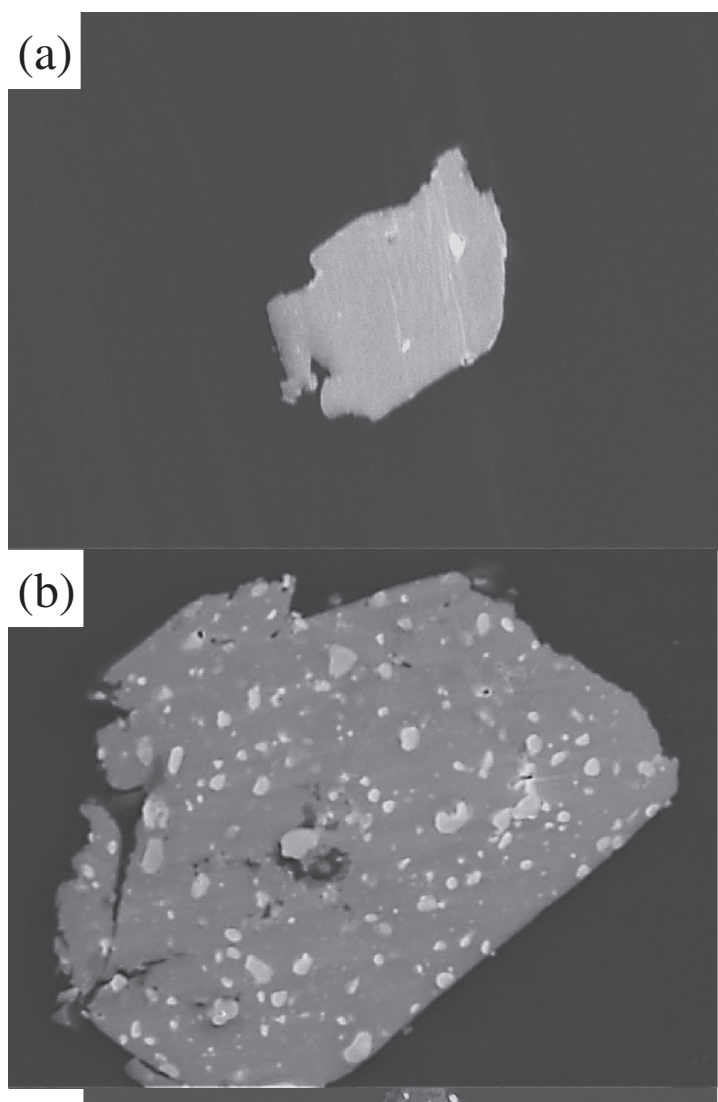

(c)

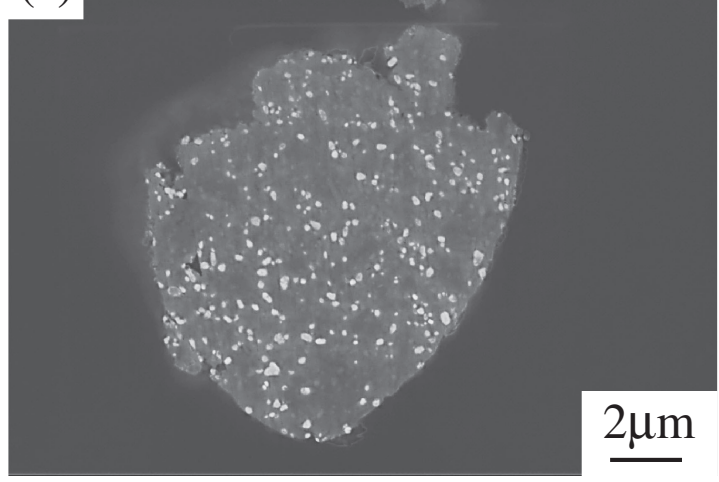

Fig. 1 SEM back scattered images of (a) $\mathrm{MM}$ powder without $\mathrm{Al}_{2} \mathrm{O}_{3}$, (b) $\mathrm{MM}$ powder with $10 \mathrm{vol} \% \mathrm{Al}_{2} \mathrm{O}_{3}$, and (c) $\mathrm{MM}$ powder with $20 \mathrm{vol} \%$ $\mathrm{Al}_{2} \mathrm{O}_{3}$.

It should be noted that the $\mathrm{Al}_{2} \mathrm{O}_{3}$ particles in $20 \mathrm{vol} \%$ composite were finer than those in the $10 \mathrm{vol} \%$ composite (Figs. 1(b) and 1(c), respectively) owing to the greater impingement of each $\mathrm{Al}_{2} \mathrm{O}_{3}$ particle during the $\mathrm{MM}$ treatment at $20 \mathrm{vol} \%$.

The microstructures of the SPS compacts obtained after sintering of the MM powders are shown in Fig. 2. The SEM micrographs in Figs. 2(a), 2(b), and 2(c) correspond to the sintered compacts of the MM powders shown in Figs. 1(a), 1(b), and 1(c), respectively. Average grain sizes of the $\mathrm{Mg}$ matrices in Figs. 2(a), 2(b), and 2(c) are approximately 4.9, 5.2 and $3.4 \mu \mathrm{m}$, respectively. The size and distribution of the $\mathrm{Al}_{2} \mathrm{O}_{3}$ particle are nearly the same before and after sintering. However, in the $\mathrm{Mg}$ composite with $20 \mathrm{vol} \% \mathrm{Al}_{2} \mathrm{O}_{3}$, many ultra-fine particles are observed in the $\mathrm{Mg}$ matrix. The porosity of $\mathrm{Mg}$ compact was estimated using several SEM
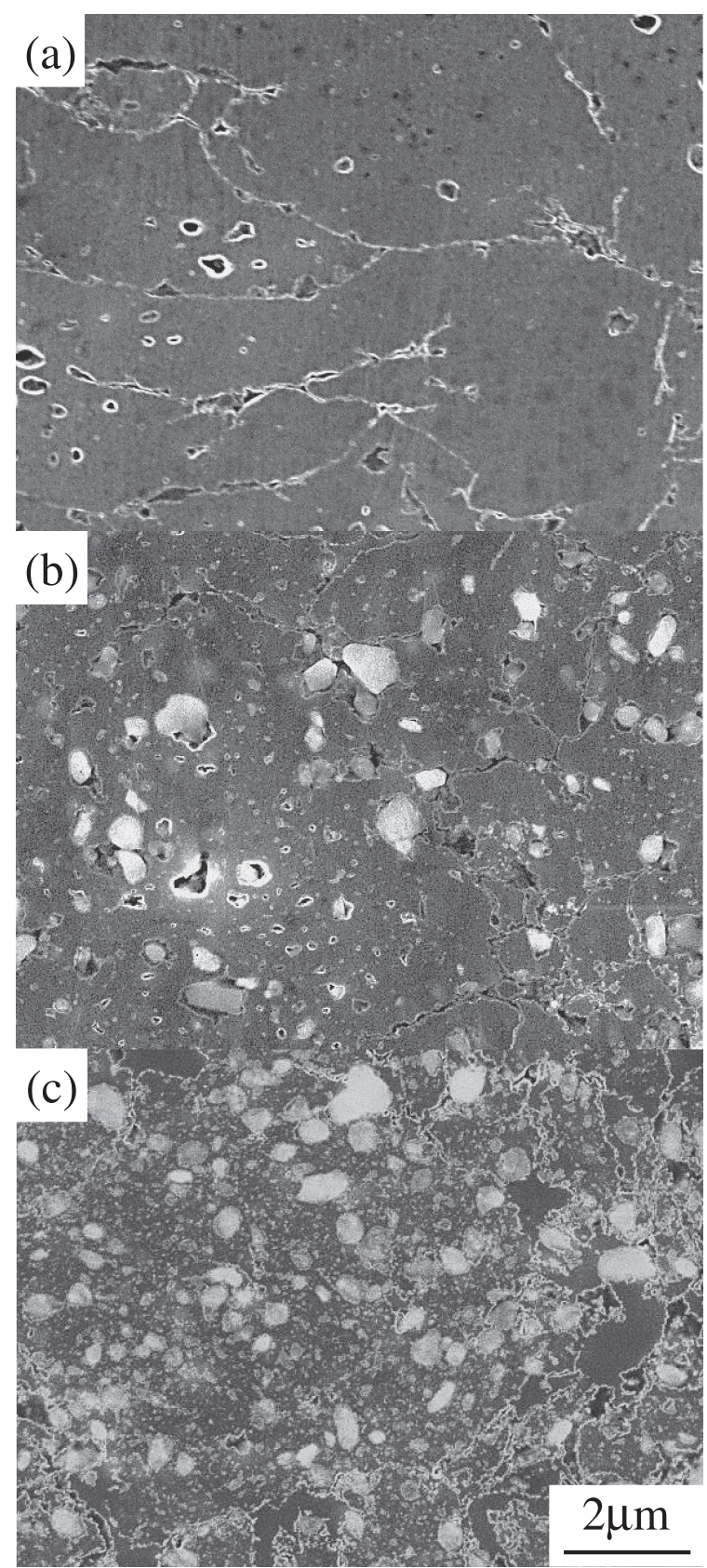

Fig. 2 SEM back scattered images of (a) SPS compact of the MM powder without $\mathrm{Al}_{2} \mathrm{O}_{3}$, (b) SPS compact of the MM powder with 10 vol\% $\mathrm{Al}_{2} \mathrm{O}_{3}$, and (c) SPS compact of the MM powder with 20 vol\% $\mathrm{Al}_{2} \mathrm{O}_{3}$.

micrographs to be $3.9 \%$ and the pores are observed in the interior of grains and at grain boundaries (Fig. 2(a)). The porosity of $\mathrm{Mg}$ composite with $10 \mathrm{vol} \% \mathrm{Al}_{2} \mathrm{O}_{3}$ was estimated using several SEM micrographs to be $2.5 \%$ and the pores are found at the interface between the $\mathrm{Mg}$ matrix and the $\mathrm{Al}_{2} \mathrm{O}_{3}$ particles, as shown in Fig. 2(b). The porosity of $\mathrm{Mg}$ composite with $20 \mathrm{vol} \% \mathrm{Al}_{2} \mathrm{O}_{3}$ was estimated using several SEM micrographs to be $2.4 \%$ and the pores are observed at the grain boundaries (Fig. 2(c)). Pores at interface between the $\mathrm{Mg}$ and $\mathrm{Al}_{2} \mathrm{O}_{3}$ particles are not observed so much in the 20 vol\% $\mathrm{Al}_{2} \mathrm{O}_{3}$ composite.

The hardness of the MM powders and the SPS compacts presented in Figs. 1 and 2 is shown in Fig. 3. The ordinate and abscissa in Fig. 3 correspond to the Vickers hardness and $\mathrm{Al}_{2} \mathrm{O}_{3}$ volume fraction, respectively. The hardness of both 


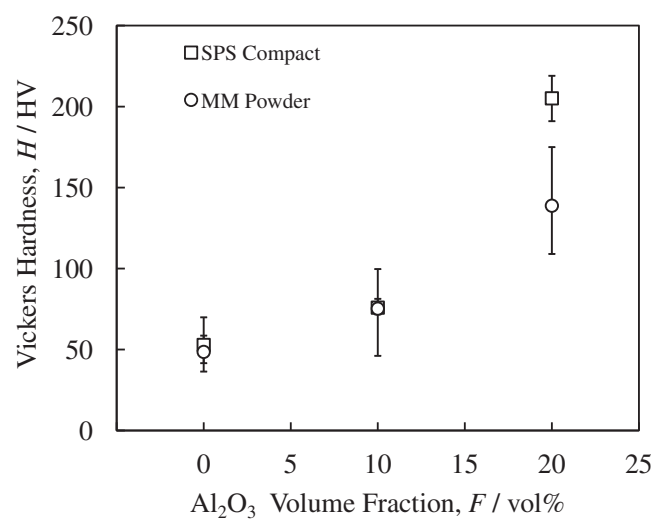

Fig. 3 Vickers hardness results for the MM powders and the SPS compacts of the $\mathrm{Mg}$ composites with 0 to $20 \mathrm{vol} \% \mathrm{Al}_{2} \mathrm{O}_{3}$.

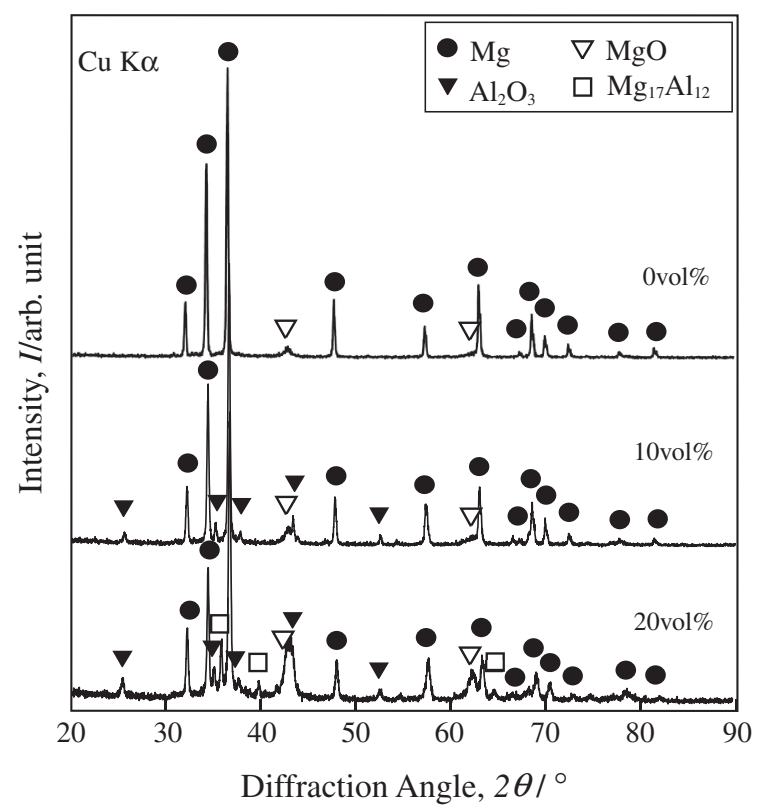

Fig. 4 XRD results for the SPS compacts of pure $\mathrm{Mg}$ and $\mathrm{Mg}$ composites with 10 and 20 vol\% $\mathrm{Al}_{2} \mathrm{O}_{3}$.

MM powder and SPS compact without $\mathrm{Al}_{2} \mathrm{O}_{3}$ is approximately $50 \mathrm{HV}$, and that of both $\mathrm{MM}$ powder and SPS compact with $10 \mathrm{vol} \% \quad \mathrm{Al}_{2} \mathrm{O}_{3}$ is approximately $75 \mathrm{HV}$. However, the hardness of the MM powder with $20 \mathrm{vol} \%$ $\mathrm{Al}_{2} \mathrm{O}_{3}$ is approximately $140 \mathrm{HV}$, while that of the SPS compact is approximately $200 \mathrm{HV}$. It is interesting to note that the hardness of SPS compact drastically raises compared to the $\mathrm{MM}$ powder when the $\mathrm{Al}_{2} \mathrm{O}_{3}$ addition changes from 10 to $20 \mathrm{vol} \%$. This drastic increase of the hardness is caused by not only effect of the $\mathrm{Al}_{2} \mathrm{O}_{3}$ addition and the grain refinement but also other effect. Therefore, in order to uncover the reason for this increase of the hardness, the microstructure of the $\mathrm{Mg}$ composites with $0-20$ vol\% $\mathrm{Al}_{2} \mathrm{O}_{3}$ were observed in detail (see below).

\subsection{Detailed microstructure of the SPS compacts with 0-20 vol\% $\mathrm{Al}_{2} \mathrm{O}_{3}$}

Figure 4 shows XRD profiles of the pure $\mathrm{Mg}$ compact and the $\mathrm{Mg}$ composites with 10 and $20 \mathrm{vol} \% \mathrm{Al}_{2} \mathrm{O}_{3}$ particles. The

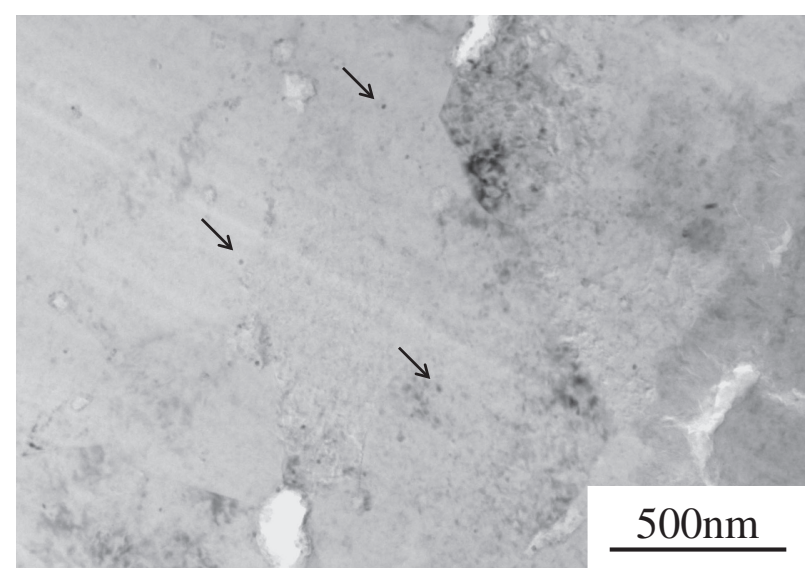

Fig. 5 TEM micrograph of the SPS compact of the pure Mg powder milled for $180 \mathrm{ks}$.

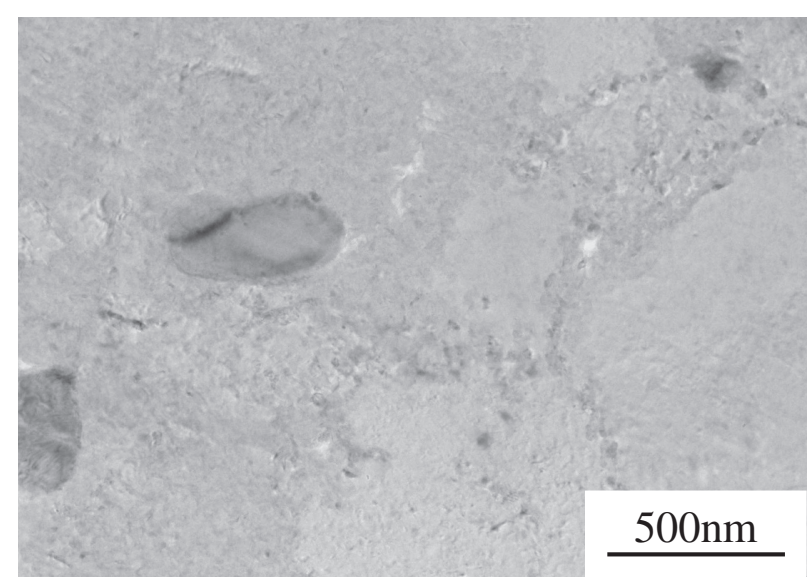

Fig. 6 TEM micrograph of the SPS compact of the Mg composite with $10 \mathrm{vol} \% \mathrm{Al}_{2} \mathrm{O}_{3}$

pure $\mathrm{Mg}$ compact consists of $\mathrm{Mg}$ and $\mathrm{MgO}$, while the $\mathrm{Mg}$ composite with $10 \mathrm{vol} \% \mathrm{Al}_{2} \mathrm{O}_{3}$ consists of $\mathrm{Mg}, \mathrm{Al}_{2} \mathrm{O}_{3}$, and $\mathrm{MgO}$, and the $\mathrm{Mg}$ composite with $20 \mathrm{vol} \% \mathrm{Al}_{2} \mathrm{O}_{3}$ consists of $\mathrm{Mg}, \mathrm{Al}_{2} \mathrm{O}_{3}, \mathrm{MgO}$, and $\mathrm{Mg}_{17} \mathrm{Al}_{12}$. The formation of the $\mathrm{Mg}_{17} \mathrm{Al}_{12}$ phase is one cause for the increased hardness of the composite with 20 vol\% $\mathrm{Al}_{2} \mathrm{O}_{3}$.

Figure 5 shows a TEM micrograph of the pure $\mathrm{Mg}$ compact of the MM powder milled for $180 \mathrm{ks}$. Some nanoparticles with a dark contrast can be observed as indicated by the arrows. Figure 6 shows a TEM micrograph of the $\mathrm{Mg}$ composite with $10 \mathrm{vol} \% \mathrm{Al}_{2} \mathrm{O}_{3}$ particles. The large particles with a dark contrast correspond to $\mathrm{Al}_{2} \mathrm{O}_{3}$. An enlargement of this TEM micrograph, along with the EDS line analysis results, is shown in Fig. 7. Nanoparticles with a size of approximately $20 \mathrm{~nm}$ are observed in Fig. 7(a). The EDS line analysis results for the horizontal line in Fig. 7(a) are shown in Fig. 7(b). The EDS profiles indicate an increase in the oxygen concentration at the position of the nanoparticles. Then, the aluminum was not detected in this area. Thus, the EDS results shown in Fig. 7 and the XRD results shown in Fig. 4 reveal that the nanoparticle in Fig. 7(a) is $\mathrm{MgO}$. Similarly, the nanoparticle shown in Fig. 5 is $\mathrm{MgO}$.

Figure 8 shows a TEM micrograph of the Mg composite with $20 \mathrm{vol} \% \quad \mathrm{Al}_{2} \mathrm{O}_{3}$. The particle with a dark contrast 


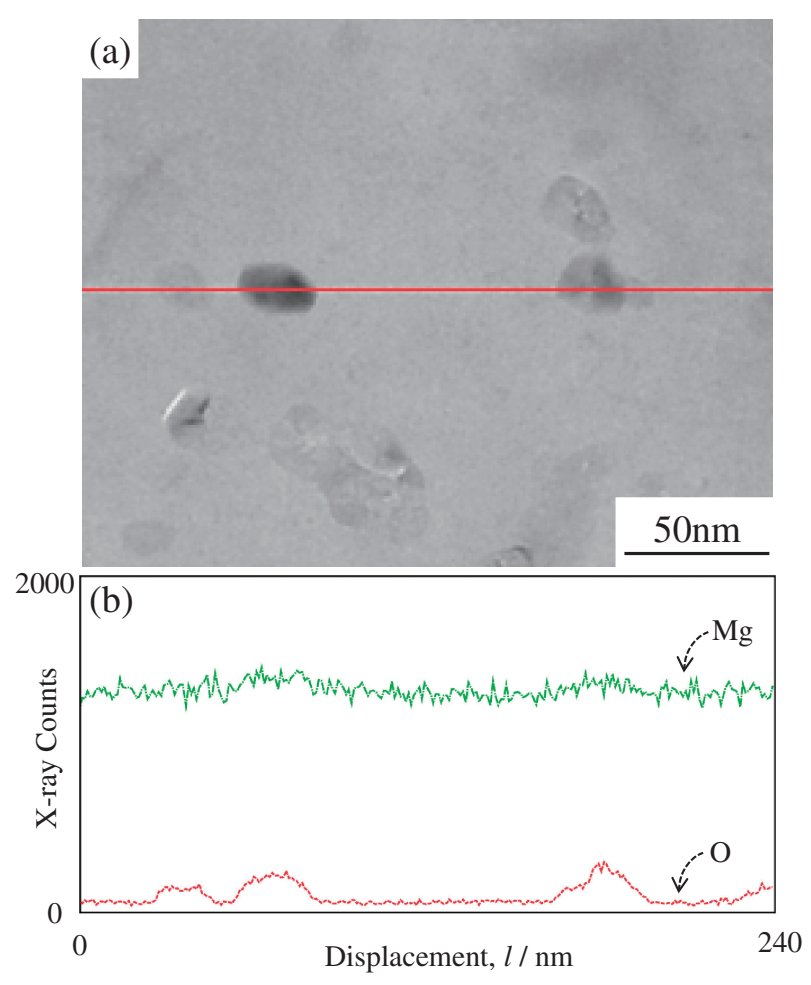

Fig. 7 TEM micrograph (a) and EDS line analysis results (b) for the SPS compact of $\mathrm{Mg}$ composite with $10 \mathrm{vol} \% \mathrm{Al}_{2} \mathrm{O}_{3}$.

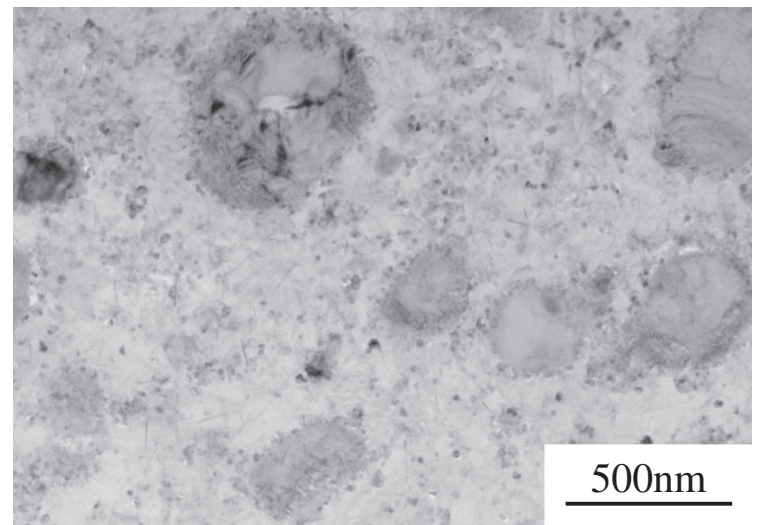

Fig. 8 TEM micrograph of the SPS compact of the $\mathrm{Mg}$ composite with $20 \mathrm{vol} \% \mathrm{Al}_{2} \mathrm{O}_{3}$.

corresponds to $\mathrm{Al}_{2} \mathrm{O}_{3}$, and a large number of very fine particles are observed in the $\mathrm{Mg}$ matrix, an enlargement of which is shown in Fig. 9. Nanosized equiaxed and needle-like precipitates are widely observed in the $\mathrm{Mg}$ matrix in this figure. It cannot be denied that a shape of the needle-like precipitates is actually plate-like. However, these are called needle-like precipitates for convenience in this paper. A TEM micrograph of the needle-like precipitates and equiaxed nanoparticles is shown in Fig. 10, along with the results of the EDS line analysis. Two needle-like precipitates are located in the middle of the micrograph, and an equiaxed nanoparticle lies at the right side of the needle-like precipitates (Fig. 10(a)). The EDS profiles for the horizontal line in Fig. 10(a) are shown in Fig. 10(b) and indicate that the aluminum concentration increased

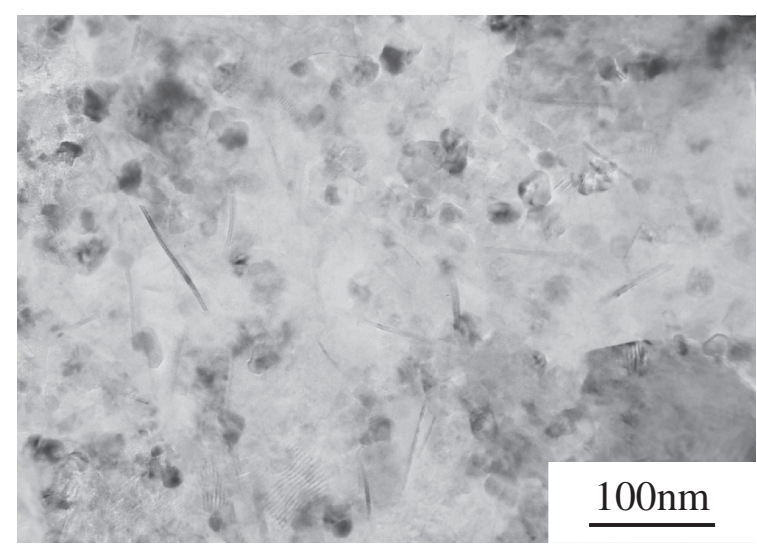

Fig. 9 High magnification image of the TEM micrograph in Fig. 8 of the $\mathrm{Mg}$ composite with $20 \mathrm{vol} \% \mathrm{Al}_{2} \mathrm{O}_{3}$.

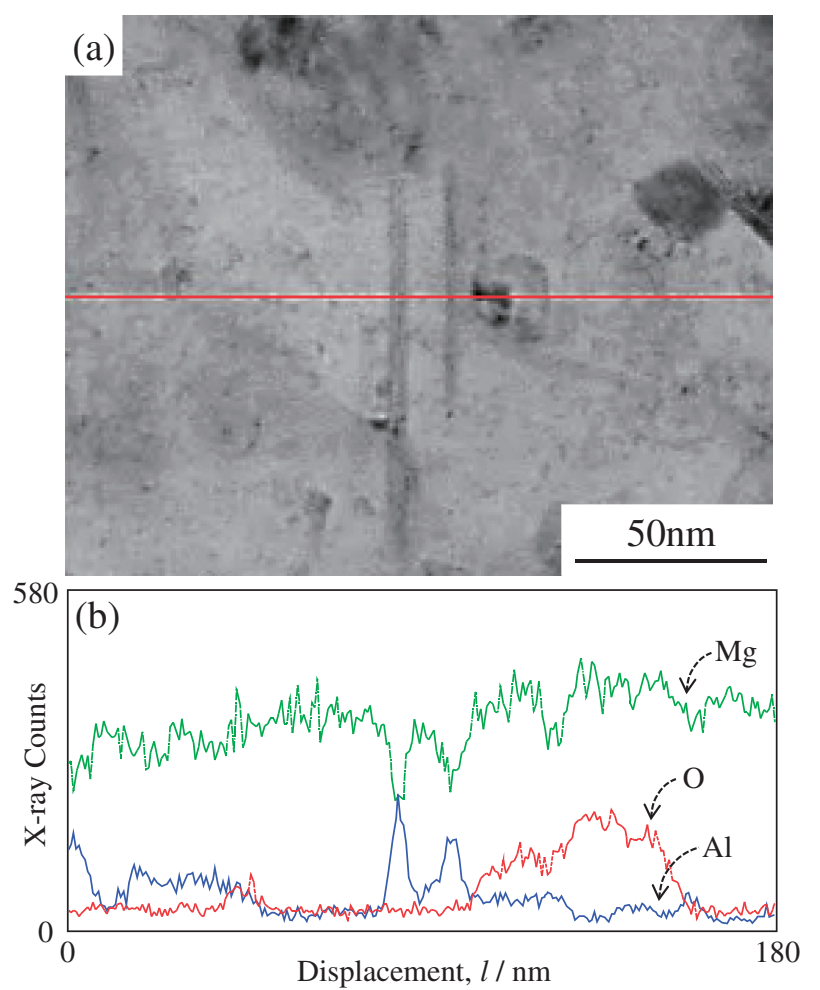

Fig. 10 TEM micrograph (a) and EDS line analysis results (b) for the $\mathrm{Mg}$ compact with $20 \mathrm{vol} \% \mathrm{Al}_{2} \mathrm{O}_{3}$.

and the magnesium concentration decreased, whereas the oxygen concentration remained unchanged at the position of needle-like precipitates. As a result, the needle-like precipitates have roughly same concentration of $\mathrm{Mg}$ and $\mathrm{Al}$. At the site of the equiaxed nanoparticle in Fig. 10(b), the oxygen concentration increased and the aluminum concentration remained unchanged. Furthermore, in Fig. 4, the formation of $\mathrm{Mg}_{17} \mathrm{Al}_{12}$ and an increase in the $\mathrm{MgO}$ concentration in the $\mathrm{Mg}$ composite containing $20 \mathrm{vol} \%$ $\mathrm{Al}_{2} \mathrm{O}_{3}$ was observed. Therefore, it was concluded the needle-like precipitates and the equiaxed nanoparticle shown in Figs. 9 and 10 correspond to $\mathrm{Mg}_{17} \mathrm{Al}_{12}$ and $\mathrm{MgO}$, respectively.

A TEM micrograph in the vicinity of the $\mathrm{Al}_{2} \mathrm{O}_{3}$ particle in the $\mathrm{Mg}$ composite with $20 \mathrm{vol} \% \mathrm{Al}_{2} \mathrm{O}_{3}$ can be seen in 


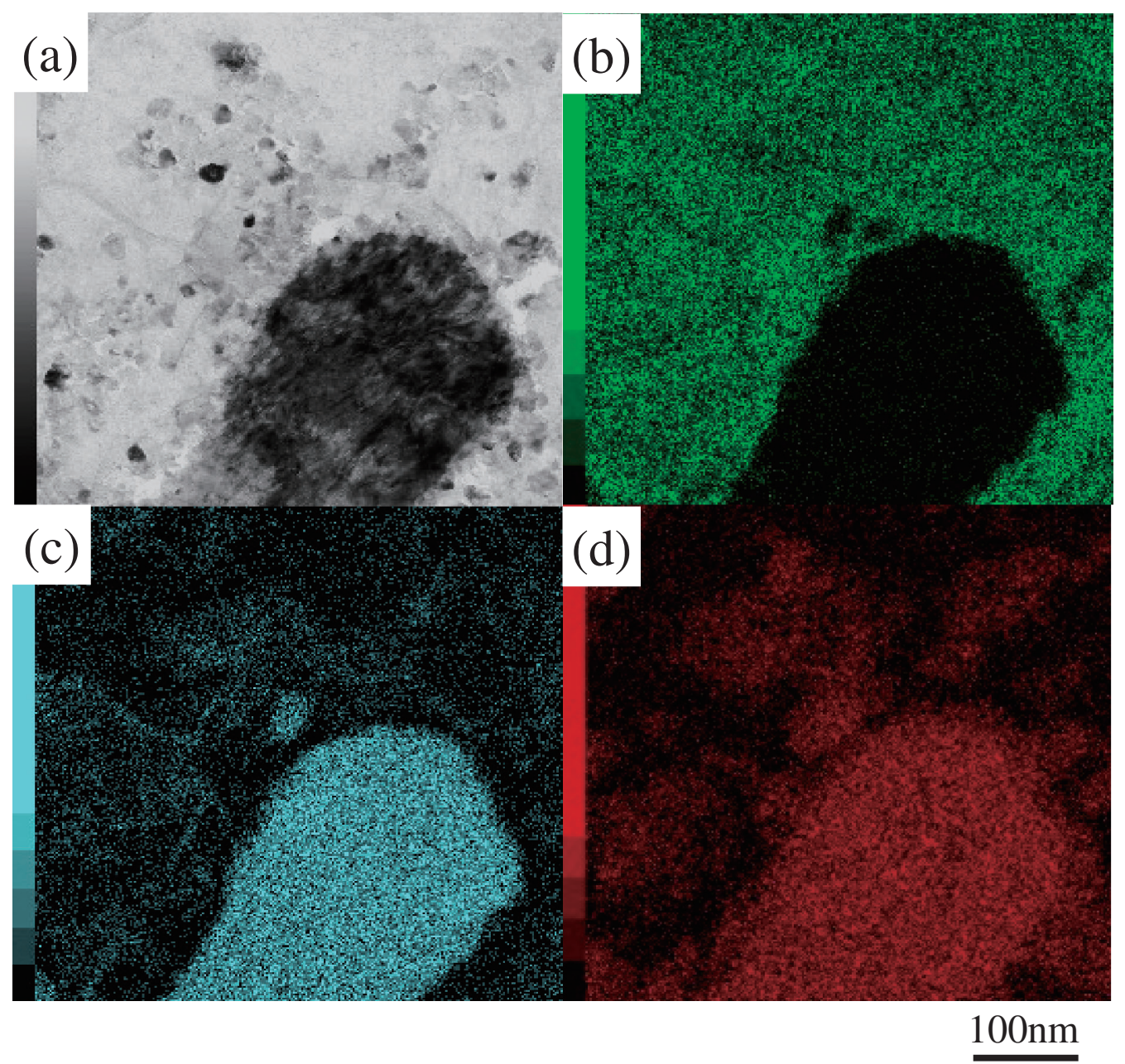

Fig. 11 EDS elemental mapping results for the SPS compact with 20 vol $\% \mathrm{Al}_{2} \mathrm{O}_{3}$.

Fig. 11(a), and the EDS mapping results for $\mathrm{Mg}, \mathrm{Al}$, and $\mathrm{O}$ can be seen in Figs. 11(b), 11(c), and 11(d), respectively. $\mathrm{Al}$ and $\mathrm{O}$ are observed in the $\mathrm{Mg}$ matrix in the vicinity of the $\mathrm{Al}_{2} \mathrm{O}_{3}$ particle as shown in Figs. 11(c) and 11(d). This result suggests that a solid-state reaction occurs in the $\mathrm{Mg}$ composite with $20 \mathrm{vol} \% \mathrm{Al}_{2} \mathrm{O}_{3}$. The solute oxygen and magnesium may immediately produce $\mathrm{MgO}$, because magnesium barely dissolves in oxygen. On the other hand, magnesium can dissolve to a significant extent in aluminum. However, the magnesium that cannot dissolve may bond to aluminum, resulting in the formation of $\mathrm{Mg}_{17} \mathrm{Al}_{12}$. Such a solid-solution reaction would occur as follows: ${ }^{11,12)}$

$$
35 \mathrm{Mg}+6 \mathrm{Al}_{2} \mathrm{O}_{3} \rightarrow \mathrm{Mg}_{17} \mathrm{Al}_{12}+18 \mathrm{MgO} \text {. }
$$

The needle-like $\mathrm{Mg}_{17} \mathrm{Al}_{12}$ and a large number of $\mathrm{MgO}$ particles are not observed in the $\mathrm{Mg}$ composite with $10 \mathrm{vol} \%$ $\mathrm{Al}_{2} \mathrm{O}_{3}$ (Fig. 6). The solid-solution reaction shown in eq. (1) is unlikely to occur because the contact area between the $\mathrm{Mg}$ matrix and the $\mathrm{Al}_{2} \mathrm{O}_{3}$ particles is reduced in correlation with the pores at the interface between the $\mathrm{Mg}$ matrix and the $\mathrm{Al}_{2} \mathrm{O}_{3}$ particles (Figs. 2(b) and 2(c)).

Therefore, a drastic increase in the hardness of the SPS compact, when the $\mathrm{Al}_{2} \mathrm{O}_{3}$ addition changes from 10 to $20 \mathrm{vol} \%$, is attributed to the formation of $\mathrm{Mg}_{17} \mathrm{Al}_{12}$ and $\mathrm{MgO}$ (Fig. 9) in the $\mathrm{Mg}$ composite with 20 vol\% $\mathrm{Al}_{2} \mathrm{O}_{3}$.

\section{Conclusion}

Magnesium composites containing 0-20 vol\% $\mathrm{Al}_{2} \mathrm{O}_{3}$ were fabricated via mechanical milling (MM) followed by spark plasma sintering (SPS). The microstructures and mechanical properties of the $\mathrm{Mg} / \mathrm{Al}_{2} \mathrm{O}_{3}$ composites were evaluated using scanning electron microscopy, transmission electron microscopy, X-ray diffraction, and the Vickers hardness test. The $\mathrm{Mg}$ compact with $10 \mathrm{vol} \% \mathrm{Al}_{2} \mathrm{O}_{3}$ consisted of an $\mathrm{Mg}$ matrix, fine $\mathrm{Al}_{2} \mathrm{O}_{3}$ particles, and nano $\mathrm{MgO}$ particles. The $\mathrm{Mg}$ compact with $20 \mathrm{vol} \% \mathrm{Al}_{2} \mathrm{O}_{3}$ consisted of an $\mathrm{Mg}$ matrix, fine $\mathrm{Al}_{2} \mathrm{O}_{3}$ particles, equiaxed nano $\mathrm{MgO}$ particles, and needlelike $\mathrm{Mg}_{17} \mathrm{Al}_{12}$ phase. The hardness of the MM powder and the SPS compact were nearly the same for the pure $\mathrm{Mg}$ and $\mathrm{Mg}$ composite with $10 \mathrm{vol} \% \mathrm{Al}_{2} \mathrm{O}_{3}$. However, the hardness of the SPS compact was higher than that of the MM powder for the $\mathrm{Mg}$ composite with $20 \mathrm{vol} \% \mathrm{Al}_{2} \mathrm{O}_{3}$. The drastic increase in the hardness of the SPS compact, when the $\mathrm{Al}_{2} \mathrm{O}_{3}$ addition changes from 10 to $20 \mathrm{vol} \%$, is attributed to the formation of the needle-like $\mathrm{Mg}_{17} \mathrm{Al}_{12}$ and equiaxed nano $\mathrm{MgO}$ particles.

\section{REFERENCES}

1) A. Yamazaki, J. Kaneko and M. Suganuma: Mater. Trans. 45 (2004) 2410-2416. 
2) A. Yamazaki, J. Kaneko and M. Suganuma: J. Jpn. Soc. Powder Powder Metall. 48 (2001) 61-66.

3) A. Yamazaki, J. Kaneko and M. Suganuma: J. Jpn. Soc. Powder Powder Metall. 48 (2001) 397-403.

4) A. Yamazaki, J. Kaneko and M. Suganuma: J. Jpn. Soc. Powder Powder Metall. 48 (2001) 935-942.

5) J. S. C. Jang, L. J. Chang, J. H. Young, J. C. Huang and C. Y. A. Tsao: Intermetallics 14 (2006) 945-950.

6) S. F. Hassan and M. Gupta: Metall. Mater. Trans. A 36 (2005) 2253 2258 .
7) S. F. Hassan and M. Gupta: Mater. Sci. Eng. A 392 (2005) 163-168.

8) S. F. Hassan and M. Gupta: Mater. Sci. Eng. A 425 (2006) 22-27.

9) S. F. Hassan and M. Gupta: J. Alloy. Compd. 419 (2006) 84-90.

10) S. Kawamori, H. Fujiwara, K. Kuroda and Y. Kasuga: Steel Res. Int., Special ed., (2012) pp. 823-826.

11) S. Kawamori, K. Kuroda, H. Fujiwara and K. Ameyama: Mater. Sci. Forum 706-709 (2012) 1915-1920.

12) S. Kawamori, K. Kuroda, Y. Kasuga, M. Yokouchi, H. Fujiwara and K. Ameyama: Mater. Trans. 51 (2010) 1893-1900.

13) S. Kawamori and T. Machida: Mater. Trans. 48 (2007) 373-379. 